\title{
Growth and Nutrient Uptake Responses of Kinnow to Vesicular Arbuscular Mycorrhizae
}

\author{
M. H. Shamshiri, K. Usha, and Bhupinder Singh \\ Division of Fruit and Horticultural Technology, Indian Agricultural Research Institute, New Delhi 110012, India \\ Correspondence should be addressed to K. Usha, ushakalidindi@yahoo.co.in
}

Received 9 August 2011; Accepted 21 September 2011

Academic Editor: X. Xu

Copyright ( $) 2012$ M. H. Shamshiri et al. This is an open access article distributed under the Creative Commons Attribution License, which permits unrestricted use, distribution, and reproduction in any medium, provided the original work is properly cited.

In a field experiment, three-year-old Kinnow trees budded on Jatti Katti (C. jambhiri) rootstock were inoculated by three different arbuscular mycorrhiza (AM), Glomus manihotis $\left(\mathrm{T}_{1}\right)$, Glomus mosseae $\left(\mathrm{T}_{2}\right)$, and Gigaspora gigantia $\left(\mathrm{T}_{3}\right)$, separately or in combination $\left(\mathrm{T}_{4}\right)$. Microscopic assessment of AM colonization on Kinnow roots showed a relatively lower level of infection by different species when inoculated separately than when inoculaed together. Application of AM improved growth parameters like plant height, canopy volume, mean leaf area, and number of new shoots per plant but had no effect on trunk diameter, number of leaf per new shoot and new shoot diameter. Flowering phenology was also altered by AM infection. The infected plants produced more flowers which despite abscission caused an increase in the initial number of fruits. AM inoculation increased plant phosphorous in $T_{3}$, potassium in $T_{1}, T_{2}, T_{3}$, calcium in $T_{2}, T_{3}, T_{4}$, and the AM-nutrient relationship did not reveal any generalized pattern. Inoculated plants, however, had higher concentration of different elements by the second year of the experiment indicating towards the continuous and cumulative effect of AM infection on plant nutrient accumulation. Further, the beneficial effects of AM on Kinnow were not related to the difference in the species of mycorrhiza.

\section{Introduction}

There have been many scientific reports suggesting that inoculation with arbuscular mycorrhiza may cause an additive or synergistic growth enhancement of the inoculated host plant [1]. Enhanced plant growth by arbuscular mycorrhizal fungi (AMF) is determined by the dependency of the plant on the fungi, the ability of the fungi to forage away from the root for nutrients, especially $\mathrm{P}$, the nutrition level of the growth medium itself, and other factors. The primary effect of AM symbiosis is to increase the supply of mineral nutrients to the plant, particularly those whose ionic forms have a poor mobility rate or those which are present in low concentration in the soil solution leading to the better growth and development of host plant [2]. It is postulated that species variation in AM fungi may cause difference in the crop growth due to their effect on certain key plant physiological processes. AM influence on optimizing the availability and uptake of mineral nutrients in the rhizosphere is one such important regulator of plant growth and development. Tang and Wan
[3] observed an increase in shoot length and leaf area of mycorrhizal citrus seedlings than noninoculated control. Inoculation with different AM species, Glomus mosseae, G. etunicatus, and G. fasciculatum, showed improved growth of citrus, ornamental, and vegetable crops [4]. Shanmugam et al. [5] found that acid lime inoculated with Glomus mosseae and G. etunicatus showed higher shoot length and leaf number. Nemec and Guy [6] reported that citrus seedlings inoculated with Glomus mosseae, G. etunicatus, and G. macrocarpus grew taller, weighed more and their leaves contained greater total soluble solids, sucrose, reducing sugars, and starch. Based on the experimental results, Shreshta et al. [7] proved that Satsuma mandarin trees inoculated with AM species, Glomus fasciculatum, G. mosseae, and Gigaspora ramisporophora, grew better compared to control. They also possessed larger leaf area, more vigorous tree growth. Melloni et al. [8] reported that Citrus limonia plants inoculated with Glomus intraradices were taller with larger stem diameter and higher shoot dry matter compared to noninoculated ones. Species differences of AM on the growth of carrot and onion 
were shown by Wang et al. [9]. Usha et al. [10] studied effects of AM fungus (Glomus deserticola) inoculation on the rhizosphere dynamics of Kinnow mandarin and found that G. deserticola modifies rhizosphere favorably to improve soil nutrient availability and consequent uptake by plant and thus results in better growth, fruit yield, and quality of Kinnow.

The present work was executed on Kinnow as its cultivation is proving to be a major attraction for fruit growers in India because of the increasing demand from consumers and the highest content of limonene, a compound which has anticancer properties. However, improving its nutritional quality is a major challenge. Physiologically, the AMFs are obligate biotrophs which can form mutualistic symbiosis, with the roots of higher plants, and can provide the hosts with water and essential nutrients. In return, photosynthetic carbon of the hosts is transported into the endosymbiotic fungi. In the natural field, Kinnow plants exhibit less root hair and thus show strong dependence on AMF to substitute partly the function of root hairs. Further, limited information is available on role of AMF species in influencing the growth and uptake of mineral nutrients in Kinnow. Field experiments were, thus, conducted on three-year-old Kinnow trees budded on Jatti Khatti (C. jambhiri) rootstock and were inoculated with three different arbuscular mycorrhizal fungus (AMF), that is, Glomus manihotis $\left(\mathrm{T}_{1}\right)$, Glomus mosseae $\left(\mathrm{T}_{2}\right)$, and Gigaspora gigantia $\left(\mathrm{T}_{3}\right)$ separately or in combination $\left(\mathrm{T}_{4}\right)$ to assess the species level variation in AM on the mineral nutrition and the growth of Kinnow.

\section{Materials and Methods}

Three-year-old Kinnow plants budded on Jatti Khatti rootstock having uniform vigor and growth and planted at $3.5 \mathrm{~m}$ $\times 3.5 \mathrm{~m}$ apart were selected for the experiment. AMF species were collected from the Division of Microbiology, I. A. R. I., New Delhi, and were multiplied using sorghum as trap plant. AMF species including Glomus manihotis, Glomus mosseae, and Gigaspora gigantia were applied to Kinnow plants alone and in combination when the root system was in active stage and when new roots were formed in February. The AMF inoculum (consisting of soil and root fragments and spores) was placed directly adjacent to plant root in the depth of 10$15 \mathrm{~cm}$ to facilitate fungal colonization of plant roots.

The experimental details were as follows:

$$
\begin{aligned}
& \mathrm{T}_{1}: \mathrm{FYM}+100 \mathrm{~g} / \text { tree Glomus manihotis, } \\
& \mathrm{T}_{2}: \mathrm{FYM}+100 \mathrm{~g} / \text { tree Gigaspora gigantia, } \\
& \mathrm{T}_{3}: \mathrm{FYM}+100 \mathrm{~g} / \text { tree Glomus mosseae, } \\
& \mathrm{T}_{4}: \mathrm{FYM}+\mathrm{T}_{1}+\mathrm{T}_{2}+\mathrm{T}_{3}, \\
& \mathrm{~T}_{0}: \mathrm{FYM} \text { alone. }
\end{aligned}
$$

To determine the percentage of AMF colonization in the treated plants, roots were collected 30 days after inoculation. The roots were rinsed free of soil and cut into $1 \mathrm{~cm}$ fragments. Root samples were cleared with $10 \%(\mathrm{w} / \mathrm{v}) \mathrm{KOH}$, stained with $0.05 \%(\mathrm{v} / \mathrm{v})$ trypan blue in lactophenol as described by Phillips and Hayman [11], and examined microscopically. Colonization was expressed as the percentage of root segments containing arbuscules and vesicles using a gridline intercept method [12].

Vegetative growth parameters including plant height, canopy volume, trunk diameter, and mean leaf area per shoot were measured from inoculation time in February $\left(S_{0}\right)$, July $\left(S_{1}\right)$, and October $\left(S_{2}\right)$ whereas new growth flush parameters including length of new shoot, number of leaf per new shoot, number of new shoot per plant, diameter of new shoot, and fresh weight of new shoot were measured at the end of growth season in October. Reproductive growth parameters including number of flowers, flower drop percentage, number of fruits, fruit drop percentage, and final number of fruits were measured two years after inoculation when the plants were five years old.

Leaf samples were collected in June and decontaminated using $0.2 \%$ Teepol solution, $0.1 \mathrm{~N} \mathrm{HCl}$, distilled water, and double-distilled water in a series. Petioles were separated from the blades, and the samples were dried in a forced draft hot air oven at $70^{\circ} \mathrm{C} \pm 1^{\circ} \mathrm{C}$ until a constant weight was reached. The samples were then ground and passed through $1 \mathrm{~mm}$ sieve and stored in air tight containers for determination of mineral nutrients. Tissue samples were wet-digested with a diacid mixture of nitric acid and perchloric acid in 9:4 ratios. Total nitrogen was determined using Kjeltec method. Leaf $\mathrm{P}$ concentration was determined colorimetrically [13], and $\mathrm{Ca}, \mathrm{Mg}, \mathrm{Zn}, \mathrm{Fe}, \mathrm{Cu}$, and $\mathrm{Mn}$ concentrations were determined by atomic absorption spectroscopy. Potassium concentration in plant leaves was determined by flame photometry.

The experiment was laid out in a randomized complete block design with five replications. Data was analyzed statistically by analysis of variance using MSTATC software. Probabilities of significance among treatments, interactions, and LSDs $(P<0.05)$ were used to compare means within and among treatments.

\section{Results}

The data revealed maximum root colonization in $\mathrm{T}_{4}(48 \%)$ followed by $\mathrm{T}_{1}(39 \%), \mathrm{T}_{3}(26 \%)$, and $\mathrm{T}_{2}(20 \%)$, respectively, (Table 1). It can be clearly seen from the data that, in general, AFM treatments increased plant height when compared with noninoculated control significantly in the first year (25$31.3 \%$ for AMF treatments and $23.5 \%$ for noninoculated control at $\mathrm{S}_{2}$ ). This promoter effect of AMF treatments started from $S_{1}$ (first year after inoculation) and continued up to the last measurement $S_{2}$ (second year after inoculation). The differences between AMF treatments and control were more obvious by second year which can be attributed to the accumulative effects of mycorrhizal application in the first and second year. The increase in canopy volume over noninoculated control and $S_{0}$ was higher only for $T_{3}$ for the both years. Although to some extent, differences were in between the treated plants and control initially, increase in canopy volume showed the same pattern with plant height in next measurements. In this connection, $\mathrm{T}_{1}$ and $\mathrm{T}_{4}$ produced the best results in both years followed by $T_{2}$ and $T_{3}$. In spite of promotive effect of different AMF treatments on trunk diameter over control, the differences between control 
TABLE 1: Mycorrhizal infection in roots of Kinnow as influenced by inoculation with different AMF.

\begin{tabular}{lc}
\hline Treatment & $\begin{array}{c}\text { Colonization } \\
\text { percentage }\end{array}$ \\
\hline $\mathrm{T}_{0}:$ FYM alone (control) & Negligible \\
$\mathrm{T}_{1}: \mathrm{FYM}+100 \mathrm{gr} /$ tree Glomus manihotis & 39 \\
$\mathrm{~T}_{2}: \mathrm{FYM}+100 \mathrm{gr} /$ tree Gigaspora gigantia & 20 \\
$\mathrm{~T}_{3}: \mathrm{FYM}+100 \mathrm{gr} /$ tree Glomus mosseae & 26 \\
$\mathrm{~T}_{4}: \mathrm{FYM}+\mathrm{T}_{1}+\mathrm{T}_{2}+\mathrm{T}_{3}$ & 48 \\
\hline
\end{tabular}

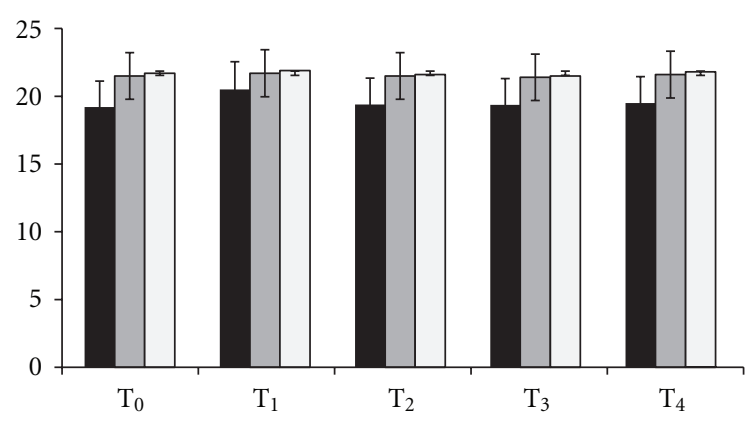

(a)

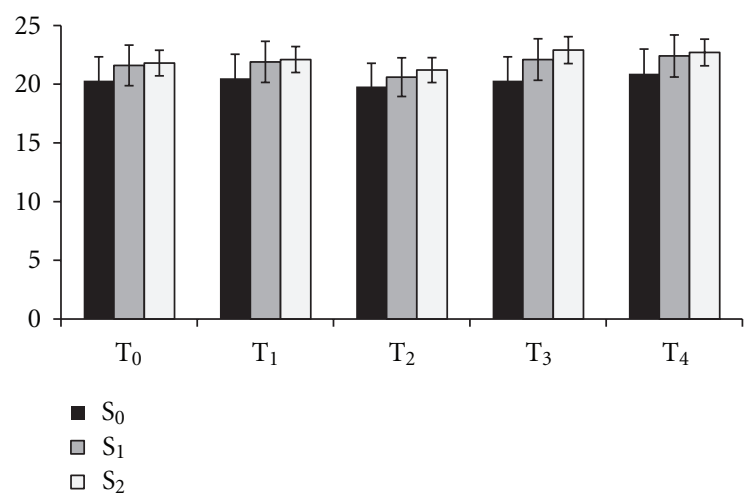

(b)

FIGURE 1: Effect of AMF treatments on mean leaf area per shoot in Kinnow over two years, that is, (a) first year and (b) second year of symbiosis.

and AMF treatment for the attribute over both years were insignificant (Table 2). In the first year, mean leaf area was affected by $T_{1}$ and $T_{4}$ significantly over control but in the second year, in spite of increase in mean leaf area during the time, the differences between the treatments over control were insignificant (Figure 1).

Length of new shoot was not affected by the treatments significantly except for $\mathrm{T}_{4}$ whereas a $50 \%$ increase in shoot length was recorded over control. Shoot length in $\mathrm{T}_{2}$ $(22.48 \mathrm{~cm})$ was distinctly but not significantly lower than the control $(26.44 \mathrm{~cm})$. AMF treatments brought no significant difference in leaf number $\left(22.75,22.75\right.$, and 23.75 for $\mathrm{T}_{2}$, $\mathrm{T}_{3}$, and $\mathrm{T}_{4}$, resp.) over control (21.25) except with $\mathrm{T}_{1}(20.5)$ where a significant decrease in leaf number was recorded.
The effect of different AMF treatments on number of new shoot per plant was found to be insignificant. However, maximum number of new shoots was obtained with $\mathrm{T}_{4}$ (148.0) followed by $\mathrm{T}_{1}$ (144.8) which were distinctly superior over control (135) and other treatments. Diameter of new shoot ranged between $0.375\left(\mathrm{~T}_{2}\right)$ and $0.501\left(\mathrm{~T}_{4}\right)$ for the AMF treatments. $\mathrm{T}_{1}$ and $\mathrm{T}_{4}$, had significantly greater diameter of $0.545 \mathrm{~cm}$ and $0.501 \mathrm{~cm}$, respectively, as compared to $\mathrm{T}_{0}(0.407 \mathrm{~cm})$. Maximum fresh weight of new shoots was recorded for $\mathrm{T}_{4}(42.3 \mathrm{~g})$, followed by $\mathrm{T}_{1}(38.35 \mathrm{~g})$, and was significantly higher over control (34.87g) and other treatments (Table 3 ).

The observations on tissue nitrogen content are presented in Table 4. All AM treatments could increase the foliar $\mathrm{N}$ level at $S_{1}$ and $S_{2}$. The range of increase in $S_{1}$ was from $12.7 \%$ with $\mathrm{T}_{4}$ to $2.12 \%$ with $\mathrm{T}_{2}$ and from $14.22 \%$ with $\mathrm{T}_{4}$ to $4.7 \%$ with $\mathrm{T}_{1}$ in $\mathrm{S}_{2}$ over control. However, the difference between AM treatments and control was not significant. The average $\mathrm{N}$ level in foliage was, in general, higher in second year after inoculation than in the first year after inoculation (1.98 and 2.24\%, resp.). Mycorrhizal treatment caused increase in foliar phosphorous content in both years as compared to control, and this promotive effect was more obvious in the second year than the first year. The highest phosphorous content of 0.514 and 0.506 percent for $\mathrm{T}_{3}$ in the first and second year, respectively, was significantly greater than the respective controls. The average $\mathrm{K}$ level in foliage was, in general, higher in second year than in the first year after inoculation. Although mycorrhizal treatments showed a higher foliage $\mathrm{K}$ in the second year and not in the first year over control, no definite trend of variation was observed for this attribute across different AMF species. The $\mathrm{K}$ concentration in the first year did not vary between mycorrhizal treatments over control while, in the second year of experiment, maximum $\mathrm{K}$ concentration of $4.11 \%$ was observed for $\mathrm{T}_{2}$ which was higher than the control $(2.31 \%)$ by about $78 \%$. Other mycorrhizal treatments in this year yielded an increase of about 33 to $44 \%$ in foliar $\mathrm{K}$ over control. Calcium was not affected by AMF treatments significantly in the first year of experimentation. On the other hand, significant difference between the treatments over control could be seen in the second year where the maximum Ca content was obtained with $\mathrm{T}_{2}(4.73 \%)$ followed by $\mathrm{T}_{3}(4.29 \%)$ and $\mathrm{T}_{4}(4.22 \%)$. Leaf magnesium content, in general, was not influenced by different AMF treatments in both investigating years with the sole exception of $\mathrm{T}_{2}$ in first year, where a magnesium content lower $(0.18 \%)$ than that of control $(0.24 \%)$ was recorded (Table 4$)$.

Zinc content did not show any significant difference among the treatments in both years although some degree of increase could be seen especially in the second year and particularly with $\mathrm{T}_{1}$, where the zinc content was much higher than control $(75.85 \%)$. The highest amount of $\mathrm{Mn}$ was obtained with $\mathrm{T}_{4}$ in both years (196.8 and $231.1 \mu \mathrm{g} / \mathrm{g} \mathrm{DW}$ ) although the difference was significantly higher over control only in the second year. Minimum amount of Mn, on the other hand, among mycorrhizal treatments was recorded for $\mathrm{T}_{2}$ (112 and $\left.184.4 \mu \mathrm{g} / \mathrm{g} \mathrm{DW}\right)$ for first and second year, respectively. A comparison of two experimental years reveals 
TABLE 2: Effect of AMF treatments on some growth parameters of Kinnow.

\begin{tabular}{|c|c|c|c|c|c|c|}
\hline \multirow{3}{*}{ Treatment } & \multicolumn{6}{|c|}{ Plant height (m) } \\
\hline & \multicolumn{3}{|c|}{ First year after inoculation } & \multicolumn{3}{|c|}{ Second year after inoculation } \\
\hline & $\mathrm{S}_{0}$ & $\mathrm{~S}_{1}$ & $\mathrm{~S}_{2}$ & $\mathrm{~S}_{0}$ & $S_{1}$ & $\mathrm{~S}_{2}$ \\
\hline $\mathrm{T}_{0}$ & 1.66 & $1.85(11.4)$ & $2.05(23.5)$ & 2.37 & $2.57(8.44)$ & $2.69(13.5)$ \\
\hline $\mathrm{T}_{1}$ & 1.76 & $2.06(17)$ & $2.31(31.3)$ & 2.66 & $2.88(8.27)$ & $3.03(13.9)$ \\
\hline $\mathrm{T}_{2}$ & 1.80 & $2.04(13.3)$ & $2.25(25)$ & 2.64 & $2.80(6.06)$ & $3.01(14)$ \\
\hline $\mathrm{T}_{3}$ & 1.79 & $2.12(18.4)$ & $2.35(31.3)$ & 2.46 & $2.79(13.41)$ & $2.85(15.85)$ \\
\hline $\mathrm{T}_{4}$ & 1.81 & $2.14(18.2)$ & $2.34(29.3)$ & 2.85 & $2.98(4.56)$ & $3.13(9.82)$ \\
\hline \multirow[t]{2}{*}{ LSD (0.05) } & & 0.163 & & & 0.289 & \\
\hline & \multicolumn{6}{|c|}{ Canopy volume $\left(\mathrm{m}^{3}\right)$} \\
\hline $\mathrm{T}_{0}$ & 6.56 & $7.27(10.8)$ & $11.3(72.3)$ & 5.24 & $7.69(46.7)$ & $9.68(84.7)$ \\
\hline $\mathrm{T}_{1}$ & 11.6 & $13.9(19.8)$ & $16.8(44.8)$ & 6.33 & $8.88(40.3)$ & $11.00(73.8)$ \\
\hline $\mathrm{T}_{2}$ & 6.99 & $9.86(41)$ & $12.2(74.5)$ & 5.71 & $8.25(44.5)$ & $10.28(80)$ \\
\hline $\mathrm{T}_{3}$ & 8.16 & $11.6(42)$ & $14.9(82.6)$ & 4.15 & $5.76(38.8)$ & $9.48(128.4)$ \\
\hline $\mathrm{T}_{4}$ & 12.27 & $15.4(25.5)$ & $18.3(49.1)$ & 7.45 & $10.16(36.4)$ & $12.78(71.54)$ \\
\hline \multirow[t]{2}{*}{$\operatorname{LSD}(0.05)$} & & 1.66 & & & 2.89 & \\
\hline & \multicolumn{6}{|c|}{ Trunk diameter $(\mathrm{cm})$} \\
\hline $\mathrm{T}_{0}$ & 5.31 & $6.05(13.9)$ & $6.60(24.3)$ & 6.73 & $7.55(12.2)$ & $8.56(28.5)$ \\
\hline $\mathrm{T}_{1}$ & 5.43 & $6.30(16)$ & $7.00(28.9)$ & 7.30 & $8.40(15.1)$ & $9.30(27.4)$ \\
\hline $\mathrm{T}_{2}$ & 5.35 & $5.93(10.8)$ & $6.38(19.3)$ & 6.76 & $7.90(16.7)$ & $8.65(28)$ \\
\hline $\mathrm{T}_{3}$ & 5.65 & $6.48(14.7)$ & $7.05(24.8)$ & 7.25 & $8.25(13.8)$ & $8.98(23.9)$ \\
\hline $\mathrm{T}_{4}$ & 5.36 & $6.49(21.1)$ & $7.58(41.4)$ & 8.00 & $8.97(12.1)$ & $9.88(23.5)$ \\
\hline LSD $(0.05)$ & & 1.08 & & & 1.49 & \\
\hline
\end{tabular}

Data in parenthesis are percentage increase over initial $\left(\mathrm{S}_{0}\right)$ for respective years. $\mathrm{T}_{0}$ : control (-AMF); $\mathrm{T}_{1}$ : Glomus manihotis; $\mathrm{T}_{2}$ : Gigaspora gigantia; $\mathrm{T}_{3}$ : Glomus mosseae; $\mathrm{T}_{4}: \mathrm{T}_{1}+\mathrm{T}_{2}+\mathrm{T}_{3}$.

$\mathrm{S}_{0}$ : February (inoculation time); $\mathrm{S}_{1}$ : July; $\mathrm{S}_{2}$ : October.

TABLE 3: Effect of different AMF treatments on new growth flush of Kinnow.

\begin{tabular}{lccccc}
\hline Treatment & Length of new Shoot $(\mathrm{cm})$ & Leaves/new shoot & New shoot/plant & Diameter of New shoot $(\mathrm{cm})$ & Fresh wt. of new shoot $(\mathrm{g})$ \\
\hline $\mathrm{T}_{0}$ & 26.44 & 21.25 & 135 & 0.407 & 34.87 \\
$\mathrm{~T}_{1}$ & 26.67 & 20.50 & 144.8 & 0.545 & 38.35 \\
$\mathrm{~T}_{2}$ & 22.48 & 22.75 & 126.8 & 0.394 & 32.47 \\
$\mathrm{~T}_{3}$ & 27.54 & 22.75 & 117.5 & 0.375 & 30.05 \\
$\mathrm{~T}_{4}$ & 40.00 & 23.75 & 148.0 & 0.501 & 42.30 \\
$\mathrm{LSD}$ & $(0.05) 3.99$ & 2.96 & 56.42 & 0.052 & 3.82 \\
\hline
\end{tabular}

$\mathrm{T}_{0}$ : control (-AMF); $\mathrm{T}_{1}$ : Glomus manihotis; $\mathrm{T}_{2}$ : Gigaspora gigantia; $\mathrm{T}_{3}$ : Glomus mosseae; $\mathrm{T}_{4}: \mathrm{T}_{1}+\mathrm{T}_{2}+\mathrm{T}_{3}$.

TABLE 4: Influence of different AMF treatments on foliar concentration of macronutrients in Kinnow.

\begin{tabular}{|c|c|c|c|c|c|c|c|c|c|c|}
\hline \multirow[t]{2}{*}{ Treatment } & \multicolumn{2}{|c|}{ Nitrogen (\%) } & \multicolumn{2}{|c|}{ Phosphorous (\%) } & \multicolumn{2}{|c|}{ Potassium (\%) } & \multicolumn{2}{|c|}{ Calcium (\%) } & \multicolumn{2}{|c|}{ Magnesium (\%) } \\
\hline & First year & $\begin{array}{c}\text { Second } \\
\text { year }\end{array}$ & First year & $\begin{array}{c}\text { Second } \\
\text { year }\end{array}$ & First year & $\begin{array}{c}\text { Second } \\
\text { year }\end{array}$ & First year & $\begin{array}{c}\text { Second } \\
\text { year }\end{array}$ & First year & $\begin{array}{c}\text { Second } \\
\text { year }\end{array}$ \\
\hline $\mathrm{T}_{0}$ & 1.89 & 2.11 & 0.243 & 0.180 & 1.03 & 2.31 & 3.670 & 3.490 & 0.24 & 0.33 \\
\hline $\mathrm{T}_{1}$ & 1.99 & 2.21 & 0.348 & 0.318 & 1.12 & 3.33 & 3.247 & 3.445 & 0.26 & 0.35 \\
\hline $\mathrm{T}_{2}$ & 1.93 & 2.23 & 0.273 & 0.251 & 1.24 & 4.11 & 3.520 & 4.735 & 0.18 & 0.33 \\
\hline $\mathrm{T}_{3}$ & 1.97 & 2.25 & 0.514 & 0.506 & 0.99 & 3.32 & 3.565 & 4.295 & 0.29 & 0.34 \\
\hline $\mathrm{T}_{4}$ & 2.13 & 2.41 & 0.423 & 0.327 & 1.25 & 3.07 & 3.472 & 4.225 & 0.29 & 0.34 \\
\hline $\operatorname{LSD}(0.05)$ & \multicolumn{2}{|c|}{0.328} & \multicolumn{2}{|c|}{0.13} & \multicolumn{2}{|c|}{0.86} & \multicolumn{2}{|c|}{0.31} & \multicolumn{2}{|c|}{0.05} \\
\hline
\end{tabular}

$\mathrm{T}_{0}$ : control (-AMF); $\mathrm{T}_{1}$ : Glomus manihotis; $\mathrm{T}_{2}$ : Gigaspora gigantia; $\mathrm{T}_{3}$ : Glomus mosseae; $\mathrm{T}_{4}$ : $\mathrm{T}_{1}+\mathrm{T}_{2}+\mathrm{T}_{3}$. 
TABLE 5: Influence of different AMF treatments on foliar concentration of micronutrients in Kinnow.

\begin{tabular}{|c|c|c|c|c|c|c|c|c|}
\hline \multirow{3}{*}{ Treatment } & \multicolumn{2}{|c|}{ Zinc } & \multicolumn{2}{|c|}{ Manganese } & \multicolumn{2}{|c|}{ Iron } & \multicolumn{2}{|c|}{ Copper } \\
\hline & \multicolumn{8}{|c|}{$(\mu \mathrm{g} / \mathrm{g} \mathrm{dw})$} \\
\hline & First year & $\begin{array}{l}\text { Second } \\
\text { year }\end{array}$ & First year & $\begin{array}{c}\text { Second } \\
\text { year }\end{array}$ & First year & $\begin{array}{c}\text { Second } \\
\text { year }\end{array}$ & First year & $\begin{array}{c}\text { Second } \\
\text { year }\end{array}$ \\
\hline $\mathrm{T}_{0}$ & 57.65 & 75.85 & 166.3 & 164.2 & 47.30 & 75.07 & 13.63 & 22.51 \\
\hline $\mathrm{T}_{1}$ & 71.10 & 97.05 & 173.8 & 197.9 & 123.3 & 154.2 & 12.11 & 21.85 \\
\hline $\mathrm{T}_{2}$ & 65.90 & 86.23 & 112.8 & 184.4 & 74.55 & 85.77 & 12.80 & 29.68 \\
\hline $\mathrm{T}_{3}$ & 69.40 & 78.92 & 166.3 & 203.9 & 72.70 & 88.15 & 13.35 & 26.55 \\
\hline $\mathrm{T}_{4}$ & 66.60 & 83.08 & 196.8 & 231.1 & 51.25 & 74.36 & 13.35 & 26.55 \\
\hline $\operatorname{LSD}(0.05)$ & \multicolumn{2}{|c|}{18.79} & \multicolumn{2}{|c|}{55.47} & \multicolumn{2}{|c|}{31.14} & \multicolumn{2}{|c|}{6.31} \\
\hline
\end{tabular}

$\mathrm{T}_{0}$ : control (non-AMF); $\mathrm{T}_{1}$ : Glomus manihotis; $\mathrm{T}_{2}$ : Gigaspora gigantia; $\mathrm{T}_{3}$ : Glomus mosseae; $\mathrm{T}_{4}: \mathrm{T}_{1}+\mathrm{T}_{2}+\mathrm{T}_{3}$.

TABLE 6: ANOVA table indicating the individual and interactive effect of AMF treatments and inoculation duration on various growth and nutritional attributes of Kinnow. (a) PH: plant height; CV: canopy Volume; TD: trunk Diameter; LA: leaf area per shoot; (b) SL: shoot length; LNS: leaves per new shoot; NSP: new shoot per plant; DNS: diameter of new shoot; FWNS: fresh weight of new shoot; (c) macro- (N, P, K, $\mathrm{Ca}, \mathrm{Mg})$ and micro- $(\mathrm{Zn}, \mathrm{Mn}, \mathrm{Fe}, \mathrm{Cu})$ nutrients.

(a)

\begin{tabular}{lccccc}
\hline SV & df & PH & MS & TD & $0.86^{* *}$ \\
Treatment (T) & 4 & $0.096^{* *}$ & $23.78^{* *}$ & $7.11^{* *}$ & $0.65^{* *}$ \\
Duration (D) & 2 & $0.447^{* *}$ & $68.39^{* *}$ & 0.03 & $10.99^{* *}$ \\
T $\times$ D & 8 & 0.002 & 0.29 & 2.01 & 0.06 \\
Error & 15 & 0.295 & 8.66 & 0.31 \\
\hline
\end{tabular}

(b)

\begin{tabular}{|c|c|c|c|c|c|c|}
\hline \multirow{2}{*}{ SV } & \multirow{2}{*}{$\mathrm{df}$} & \multicolumn{5}{|c|}{ MS } \\
\hline & & SL & LNS & NSP & DNS & FWNS \\
\hline Treatment & 4 & $132.694^{* *}$ & $5.100^{*}$ & $477.636^{* *}$ & $0.01656^{* *}$ & $70.188^{* *}$ \\
\hline Error & 8 & 1.905 & 1.207 & 14.480 & 0.00013 & 0.826 \\
\hline
\end{tabular}

(c)

\begin{tabular}{|c|c|c|c|c|c|c|c|c|c|c|}
\hline \multirow{2}{*}{ SV } & \multirow{2}{*}{ df } & \multicolumn{9}{|c|}{ MS } \\
\hline & & $\mathrm{N}$ & $\mathrm{P}$ & K & $\mathrm{Ca}$ & $\mathrm{Mg}$ & $\mathrm{Zn}$ & $\mathrm{Mn}$ & $\mathrm{Fe}$ & $\mathrm{Cu}$ \\
\hline $\mathrm{T}$ & 4 & $0.058^{* *}$ & $0.0791^{* *}$ & 0.762 & 0.563 & 0.0039 & $228.2^{* *}$ & 3624.1 & $5989.6^{* *}$ & 17.2 \\
\hline $\mathrm{D}$ & 2 & $0.507 * *$ & $0.0144^{* *}$ & $33.138^{* *}$ & $2.213^{* *}$ & $0.0555^{* *}$ & $2456.0 * *$ & $8217.1^{* *}$ & $3527.1^{* *}$ & $1149.5^{* *}$ \\
\hline $\mathrm{T} \times \mathrm{D}$ & 8 & 0.002 & $0.0019^{* *}$ & $0.528^{* *}$ & $0.440^{* *}$ & $0.0025^{* *}$ & $53.6^{* *}$ & $1059.0^{* *}$ & $102.9^{* *}$ & $15.3^{* *}$ \\
\hline Error & 15 & 0.014 & 0.0003 & 0.106 & 0.034 & 0.0002 & 11.4 & 64.5 & 15.9 & 1.0 \\
\hline
\end{tabular}

${ }^{*} P<0.05,{ }^{* *} P<0.01$.

that the Mn level increased with time more so in the mycorrhizal treatments. Mean average $\mathrm{T}_{1}$ to $\mathrm{T}_{4}$ for first and second years were (162.4 and 204.3) than the control which did not differ between two years (166.3 and $164.2 \mu \mathrm{g} / \mathrm{g}$ DW, resp.). Leaf Fe content did not show any significant difference under influence of different AMF treatments except with $\mathrm{T}_{1}$ where a sharp increase in Fe content could be observed in both years (123.3 and $154.2 \mu \mathrm{g} / \mathrm{g}$ DW, resp.) which was significantly higher than the control (47.3 and $75.07 \mu \mathrm{g} / \mathrm{g}$ DW). Other mycorrhiza in any of the years could not enhance Fe content significantly over control. There was a general increase in Fe content from the first to the second year of experimentation (73.82 and $95.51 \mu \mathrm{g} / \mathrm{g}$ DW, resp.).
Copper content, in general, increased over time from the first $(13.04 \%)$ to second year $(25.42 \%)$. Different AMF treatments with an exception of $\mathrm{T}_{1}$ in second year could increase the copper content significantly over control. Maximum concentration of $\mathrm{Cu}$ of $29.08 \mu \mathrm{g} / \mathrm{g}$ DW was obtained with $\mathrm{T}_{4}$ which was significantly higher over control but was similar to those of $\mathrm{T}_{3}$ and $\mathrm{T}_{4}$. No significant difference for $\mathrm{Cu}$ concentration among AMF treated and untreated control leaves was recorded in the first year of inoculation (Table 5). Highly significant $(P=0.01)$ individual effects of AM treatment and inoculation duration were observed on the plant height, canopy volume, trunk diameter, and leaf area per shoot (Table 6(a)). Effects of AM treatment were 
significant $(P=0.05)$ and highly significant $(P=0.01)$ for new shoot growth traits (Table 6(b)). Treatment level differences for different mineral nutrients were insignificant for $\mathrm{K}, \mathrm{Ca}, \mathrm{Mg}, \mathrm{Mn}$, and $\mathrm{Cu}$ but were significant for $\mathrm{N}, \mathrm{P}, \mathrm{Zn}$, and $\mathrm{Fe}$. Am interaction with inoculation duration was significant for all mineral nutrients except nitrogen (Table 6(c)).

\section{Discussion}

The extent of root infection in inoculated plants was lower in single strain treatments compared with mixed inoculate although, in general, the rate of root colonization was under our expectation. These results can be correlated to sufficient $\mathrm{P}$ level in treated as well as control plants that agree with findings reported on reverse relation between plant $\mathrm{P}$ content and extent of AM fungi colonization. Antunes and Cardoso [14] reported that different combinations of AM fungi and citrus species led to a reduction in percentage root infection due to soil $\mathrm{P}$ increases from 0 to $100 \mathrm{ppm}$ with Rangpur lime and with sweet orange. The mycorrhizae root infection positively correlated with the amount of inoculums used [15]. In our study, use of $100 \mathrm{~g}$ of inocula would also be responsible factor for low colonization in treated plants. Presence of moderately deep and extended root system of Kinnow in one hand and competition with local AMF strains in the other hand would have resulted in lower colonization rate of our strains.

Mycorrhizal fungi added to fumigated, steamed, or autoclaved soils have been shown to increase growth of citrus up to $108.9 \%$ [16]. In the present study, plants inoculated with different AMF treatments in field soil grew better in general compared with noninoculated plants; however, the differences were significant at all intervals of observation only with $\mathrm{T}_{4}$ where the most effective and infective inoculum was the mixed one and $\mathrm{T}_{2}$ (Gigaspora gigantia) was least effective and infective at the same time. However, it must be noticed that promotive effects of AMF on plant growth parameters are more obvious when the plants are under nutrient deficient condition in general and phosphorous deficiency in specific. Foliar phosphorous content of our inoculated and noninoculated plants was in the sufficient stage based on the report of Chahill et al. [17] who found the amount of $0.09 \% P$ as a deficiency threshold in Kinnow. Reproductive growth of mycorrhizal Kinnow plants was also affected to some extent due to an increase in flower production and initial fruit set (data not shown). Flowering phenology was altered by infection as it increased total number of flowers produced; however, the final fruit number was similar for the treatments as well as control. Mycorrhizal infection has been shown to increase flower bud production in pepper and flower number in soybean. In these cases, positive effects of mycorrhizal infection were associated with increase in phosphorous uptake. The flowering phenology may be related to plant size or resource accumulation, therefore, to the extent that mycorrhizal infection affects growth and nutrient uptake, one should expect AM infection to play a role in determining the pattern of flowering. Wang et al. [9] showed that, compared with the nonmycorrhizal controls, both shoot and root fresh weights of onion and carrot were significantly increased by AM inoculations. Further, the AM inoculation significantly decreased the pesticide "Phoxim" concentrations in shoots, roots, and soils. A variation in crop response to the AM species showed that G. intraradices BEG 141 had more pronounced effects than G. mosseae BEGS 167 on the increase of fresh weight production in both carrot and green onion. The concentration of the macroand micronutrients in Kinnow leaf tissue was more or less affected by different AM fungi treatments but no species could be characterized as dominant to affect availability and plant uptake of all elements and did not follow a specific pattern, for example, calcium content increased by $T_{2}, T_{3}$, $\mathrm{T}_{4}$ while $\mathrm{Mg}$ was not affected by any of the treatments. However, as mentioned before, there is no regular pattern followed by AMF in absorption of these elements and reports on the nutrient uptake by AMF are conflicting [18]. The conflict is amply evident from the work of Covacevich and Echeverría [19] who studied the receptivity of Argentinean soil to AM and found that inoculation with G. claroideum and A. longula alone is less promising in the field but, however, when these are added along with or in addition to the fertilizer, mycorrhizal receptivity of shoot, the grain dry matter and $\mathrm{P}$ uptake are significantly bettered than compared to noninoculated plants.

\section{Conclusion}

The continued and nonjudicious use of fertilizers and manures for agriculture often results in unexpected harmful environmental effects which can be warded off to some extent using microbial inoculants. The present investigations revealed that AM colonization on Kinnow roots was high when all the three species were present in the rhizosphere than when they were applied individually. AMF inoculated plants showed improved growth parameters like plant height, canopy volume, mean leaf area, and number of new shoots per plant, flowering, and fruit set. Higher concentration of different elements by the second year of the experiment indicated the continuous and cumulative effect of AMF infection on plant nutrient accumulation. This study provides evidence for the difference in root colonization efficiency within AM species. AM application improved growth attributes of existing and newly developing shoots. Flowering and fruiting were also bettered by AM inoculation. The fact that the inoculated plants had a significantly higher concentration of different elements when cocultivated over an extended period of symbiosis suggests that AMF should be included in nutrient management practices in Kinnow for improving the tree growth and fruit yields. Further studies on combining microbial inoculants with reduced rates of fertilizer application should be conducted.

\section{References}

[1] M. Parniske, "Arbuscular mycorrhiza: the mother of plant root endosymbioses," Nature Reviews Microbiology, vol. 6, no. 10, pp. 763-775, 2008.

[2] F. Ercolin and D. Reinhardt, "Successful joint ventures of plants: arbuscular mycorrhiza and beyond," Trends in Plant Science, vol. 16, no. 7, pp. 356-362, 2011. 
[3] Z. Y. Tang and Z. L. Wan, "Effect of inoculation of mycorrhizal fungi on phosphorous nutrition and growth of citrus," Acta Pedologica Sinica, vol. 17, no. 4, pp. 336-345, 1980.

[4] A. C. Graw and N. C. Schenck, "Growth stimulation of citrus, ornamental and vegetable crops by selected mycorrhizl fungi," Proceedings of the Florida State Horticultural Society, vol. 93, pp. 201-205, 1981.

[5] N. Shanmugam, R. C. Babu, and C. Thalamuthu, "Studies on the response of acid lime (Citrus aurantifolia Swingl.) to vesicular arbuscular mycorrhizae," Current Science, vol. 50, no. 17, pp. 772-773, 1981

[6] S. Nemec and G. Guy, "Carbohydrate status of mycorrhizal and non-mycorrhizal citrus rootstock," Journal of the American Society for Horticultural Science, vol. 107, no. 2, pp. 117$118,1982$.

[7] Y. H. Shreshta, T. Ishii, and K. Kadoya, "Effect of vesiculararbuscular mycorrhizal fungi on the growth, photosynthesis, transpiration and the distribution of photosynthates of bearing satsuma mandarin trees," Journal of the Japanese Society for Horticultural Science, vol. 64, no. 3, pp. 517-525, 1995.

[8] R. Melloni, M. A. Nogueira, V. F. Freire, and E. J. B. N. Cardoso, "Phosphorous levels and arbuscular mycorrhizal fungi on growth and mineral nutrition of Citrus limonia L. Osbeck," Revista Brasileria de Ciencia de Solo, vol. 24, no. 4, pp. 767-775, 2001.

[9] F. Y. Wang, R. J. Tong, Z. Y. Shi, X. F. Xu, and X. H. $\mathrm{He}$, "Inoculations with Arbuscular mycorrhizal fungi increase vegetable yields and decrease phoxim concentrations in carrot and green onion and their soils," PLoS One, vol. 6, no. 2, Article ID e16949, 2011.

[10] K. Usha, A. Saxena, and B. Singh, "Rhizosphere dynamics influenced by arbuscular mycorrhizal fungus (Glomus deserticola) and related changes in leaf nutrient status and yield of Kinnow mandarin King (Citrus nobilis) x Willow Leaf (Citrus deliciosa)," Australian Journal of Agricultural Research, vol. 55, no. 5, pp. 571-576, 2004.

[11] J. Phillips and D. Hayman, "Improved procedures for clearing roots and staining parasitic and vesicular-arbuscular-mycorrhizal fungi for rapid assessment of infection," Transactions of the British Mycological Society, vol. 55, pp. 158-161, 1970.

[12] B. Bierman and R. Linderman, "Quantifying vesiculararbuscular-mycorrhiza proposed methods towards standardization," New Phytologist, vol. 87, pp. 63-67, 1981.

[13] S. R. Olsen, C.V. Cole, F. S. Watanabe, and L. A. Dean, Estimation of Available $P$ in Soils by Extraction with Sodium Bicarbonate, U.S. Department of Agriculture Circular, 1954.

[14] V. Antunes and E. J. B. N. Cardoso, "Growth and nutrient status of citrus plants as influenced by mycorrhiza and phosphorus application," Plant and Soil, vol. 131, no. 1, pp. 11-19, 1991.

[15] I. Oras, "The influence of use of different rates of mycorrhizal inoculum on root infection, plant growth, and phosphorus uptake," Communications in Soil Science and Plant Analysis, vol. 27, no. 18-20, pp. 2935-2946, 1996.

[16] J. A. Menge, D. Steirle, D. G. Bagyaraj, E. L. V. Johnson, and R. T. Leonard, "Phosphorous concentrations in plants responsible for inhibition of mycorrhizal infection," New Phytologist, vol. 80, pp. 575-578, 1978.

[17] B. S. Chahill, A. S. Dhatt, R. Singh, and D. S. Dhillon, "Studies on the leaf nutrient standards in Kinnow," Indian Journal of Horticulture, vol. 48, pp. 315-320, 1991.
[18] R. M. Augè, "Water relations, drought and vesicular-arbuscular mycorrhizal symbiosis," Mycorrhiza, vol. 11, no. 1, pp. $3-42,2001$.

[19] F. Covacevich and H. E. Echeverría, "Receptivity of an argentinean pampas soil to arbuscular mycorrhizal glomus and acaulospora strains," World Journal of Agricultural Sciences, vol. 4, no. 6, pp. 688-698, 2008. 


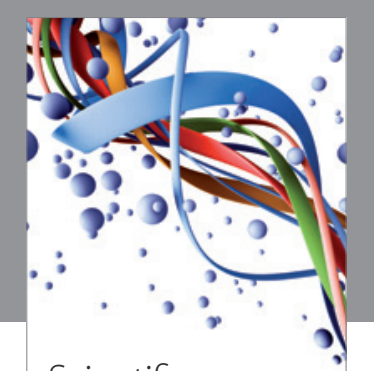

Scientifica
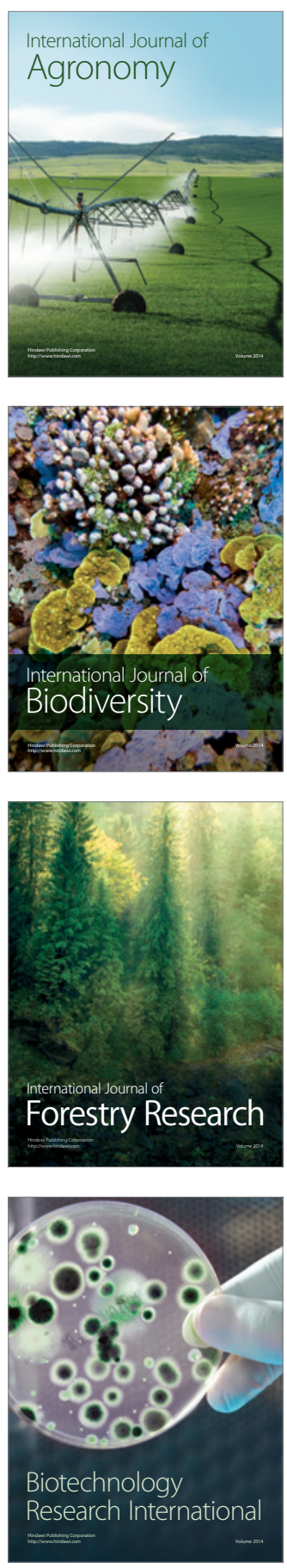
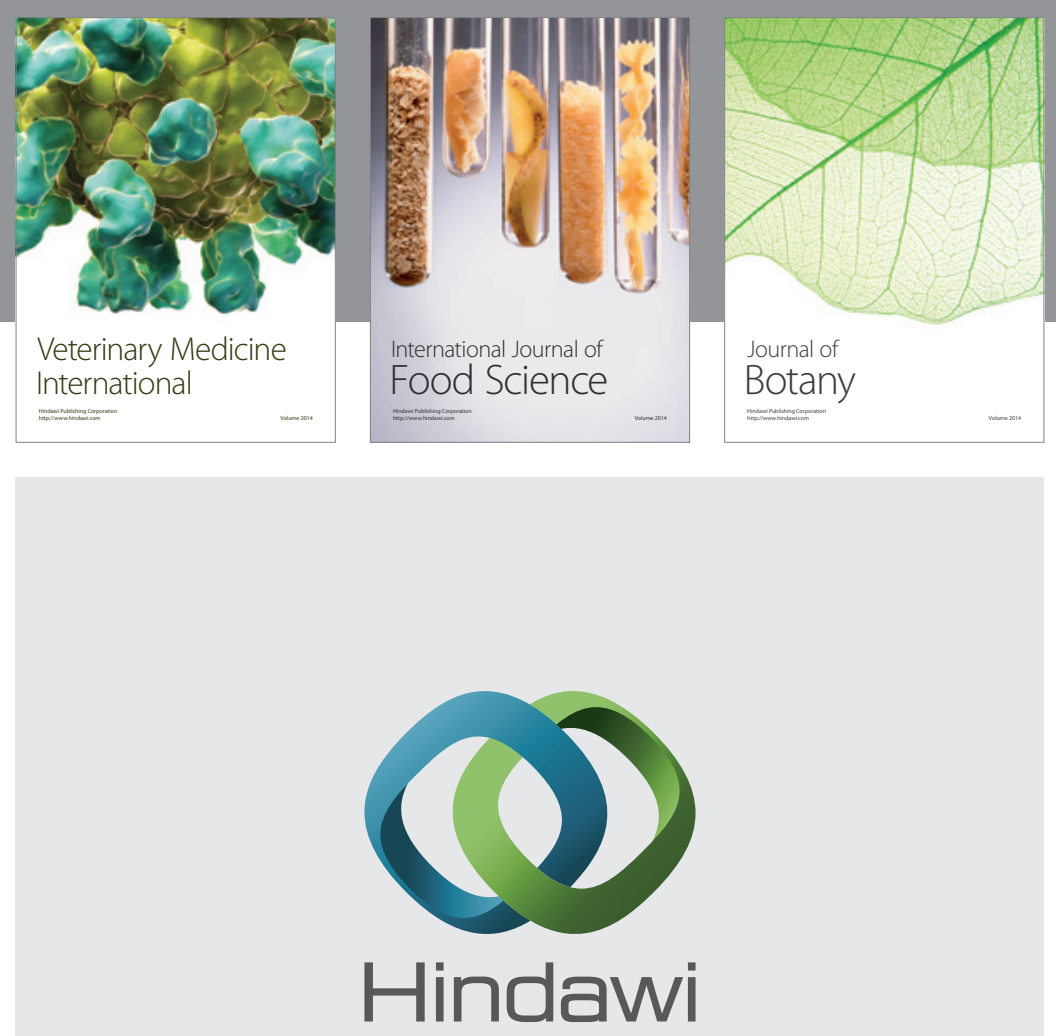

Submit your manuscripts at

http://www.hindawi.com
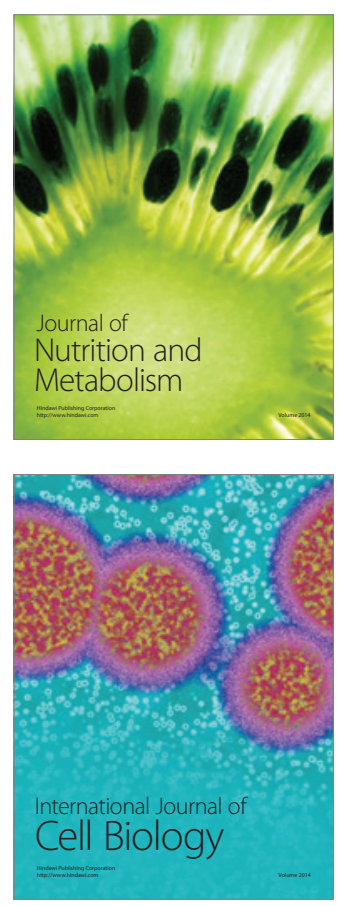
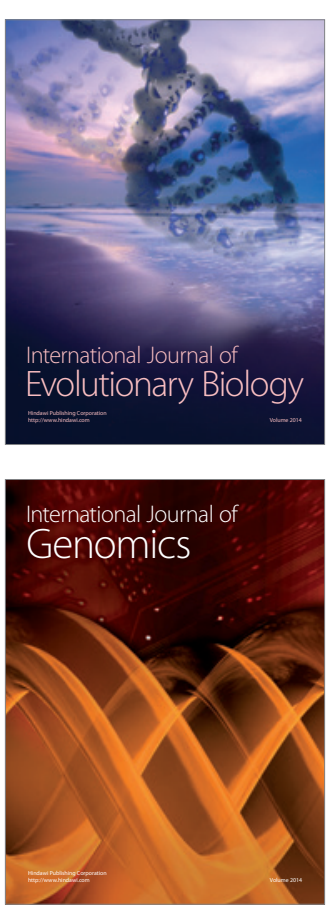
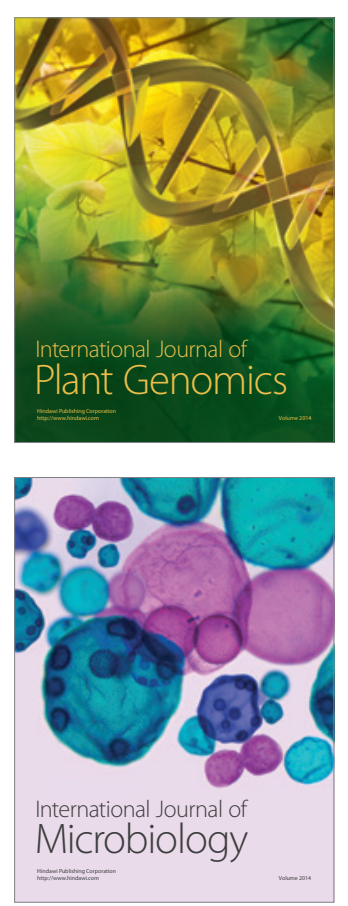

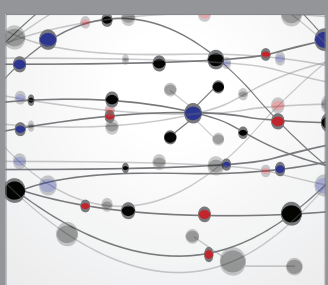

The Scientific World Journal
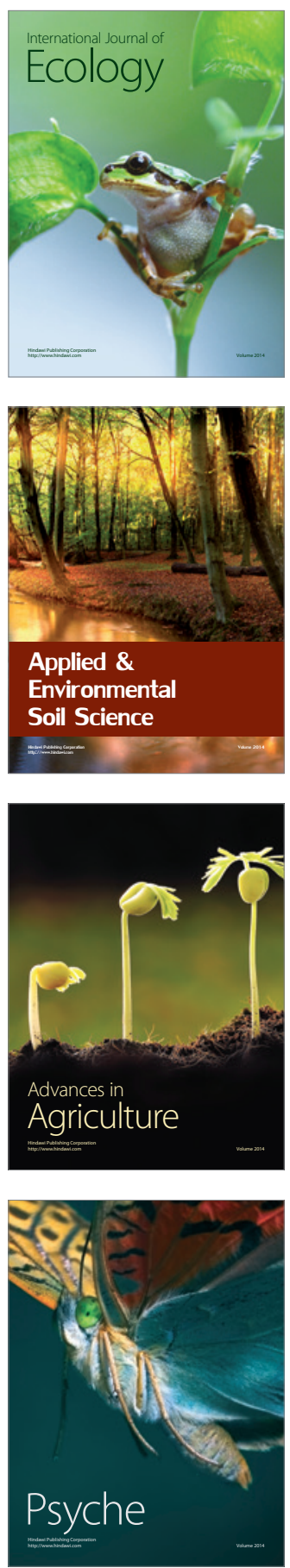